\title{
ИССЛЕДОВАНИЕ ТОПОНИМОВ КОЛОСОВСКОГО РАЙОНА
}

\author{
О. В. Кушнарева, Ж. В. Лазарева \\ Омский государственный педагогический университет, Россия \\ Поступила в редакцию 10 октября 2018 г.
}

\begin{abstract}
Аннотация: В данной статье рассматривается роль топонимов в жизни общества и представлены результаты исследования топонимов (географических названий) Колосовского района Омской области.
\end{abstract}

Ключевые слова: краеведение, топонимика, топонимы, географические названия, географические объекты, ойконимы, гидронимы.

Abstract: The article discusses the role of the toponyms in life of society and presents the results of the study of the toponyms (geographical names) in the Kolosovsky district of the Omsk region.

Key words: local history, toponymy, toponyms, geographical names, geographical objects, oikonyms, hydronyms.

Для формирования целостной географической картины мира, необходимы знания о своем родном крае. Одним из направлений краеведческой работы является изучение топонимов - названий географических объектов.

Топонимы очень прочно осели в нашей повседневной жизни, хотя обычный человек даже не задумывается об этом. Чем больше появляется новых объектов, требующих названий, тем возрастает их роль и значение в жизни общества. Топонимы включают в себя историю, географические аспекты, лингвистические особенности, культуру и традиции населения.

Топонимика находится на стыке трех наук географии, истории и лингвистики. Если основа топонимики - география, то ее временная обусловленность - история, а лингвистика выступает как лексическое выражение первой и второй.

Одно из понятий топонимики дается в «Географическом энциклопедическом словаре: понятия и термины». Топонимика - отрасль знания, всесторонне изучающая географические названия, их происхождение, смысловое значение, изменения написания, произношения и т.д. [5].

Вопросами топонимики занимались многие ученые, такие как Селищев А. М., Мурзаев Э. М., Успенский Л. В., Никонов В. А., Суперанская А. В.,

(С) Кушнарева О.В., Лазарева Ж.В., 2019
Попов А.И., Поспелов Е.М., Малолетко А.М. и другие. Большой вклад в развитие топонимики, как науки, был внесен в 60-е и 70-е годы прошлого столетия. В это время разрабатывались классификации географических названий, методология исследования географических топонимов, определялась роль топонимов в жизни населения.

Географические названия Омского региона исследовали Огурцов С. А., Кожухарь А. А., Большаник П.В., Азарова Л.В., Гвоздев Б. С., Колесников А. Д., Гурьев Г. Ю. и другие. Безусловно, исследовано большое количество топонимов Омской области, а особенно города Омска, но отдельно собранных топонимических данных по районам области практически нет. Колосовский район не стал исключением.

Рассмотрев различные подходы и методы изучения географических названий, для исследования топонимов Колосовского района были использованы следующие методы: 1) картографический метод позволяет определить местонахождение топонима на карте и расположенные вокруг него другие географические объекты, установить - есть ли топонимическая связь между ними, а с помощью статистических данных указать распространение или плотность топонимов, имеющих одинаковое окончание; 2) исторического анализа помогают определить, как и с какой стороны шло заселение территории, с какими событиями свя- 


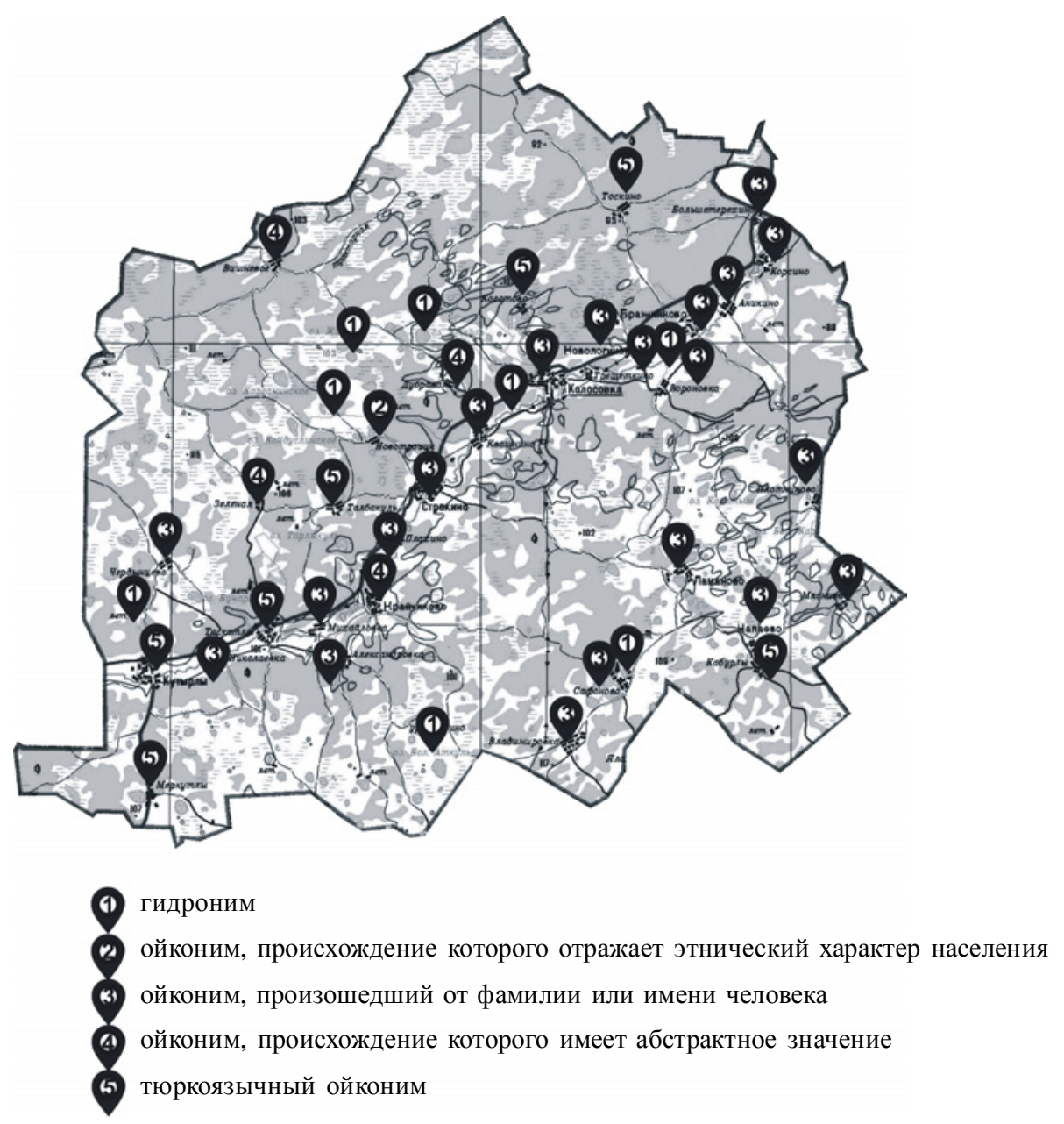

Puc. Карта топонимов Колосовского района Омской области, в соответствии с использованными классификациями

занно появление новых населенных пунктов, почему практически все гидронимы имеют иноязычное происхождение; 3) этимологический метод помогает раскрывать смысл, привычных для слуха, названий географических объектов, как русскоязычных, так и топонимов пришедших из тюркских языков. Использование всех этих методов позволило составить полное представление о названиях географических объектов Колосовского района.

Топонимы собирались из разных источников: материалы историко-краеведческого музея Колосовского муниципального района Омской области и библиотек района, статьи научных журналов и газеты «Новый Вымпел», рассказы местных жителей, а так же перевод тюркоязычных топонимов с помощью словарей.

Топонимы классифицировались следующим образом.

По схеме Э. М. Мурзаева [1], изучаемые топонимы Колосовского района можно разделить на гидронимы и ойконимы.
Географические названия, имеющие русское происхождение, классифицировались по схеме А. М. Селищева [2].

Ойконимы, имеющие тюркское происхождение, выделены в отдельную группу - тюркоязычные ойконимы.

Проанализировав топонимы Колосовского района за последнее 185 лет, непроизвольно внимание притягивается к особенностям названий населенных пунктов, например, деревни с компактным проживанием татар созвучны по названию с русскими (деревня Тоскино), а русские - имеют татарские названия (Талбакуль); или почему в большинстве своем села, расположенные на территории района, имеют окончание «...о».

Изучая научные работы по этнической истории и традиционной культуре Омского Прииртышья, анализируя собранный местными краеведами материал по топонимам, можно сделать следующие предположения, почему населенные пункты, имеют именно такие названия. 
1. Населенный пункт назывался по подобию предыдущего. Изначально в списке Тарского уезда деревни имели другие окончания - Терехина, Корсина, Аникина, Бражникова. В настоящее время, большинство сел Колосовского района имеют окончание «о» (рис.), надо полагать просто так изменилось со временем.

2. В названии поселений присутствует определенная привязка к местности. В основном она прослеживается в тюркоязычных названиях - Талбакуль, Тоскино, Кутырлы.

3. Влияние переселенцев на названия поселений. Александровка, Владимировка, Михайловка, Вороновка, Николаевка - даты образования этих сел между 1850-1898 годами, это время, когда в результате реформ и последовавшей отмены крепостного права (1861 год), в Сибирь хлынул поток переселенцев, в основном из таких губерний как: Орловская, Витебская, Полтавская, Вятская и других. Переселенцы называли вновь образованные населенные пункты, по подобию того, как они были названы в местах, из которых они приехали. Впоследствии на карте района, появляются топонимы с нехарактерным для данной местности окончанием «ка».

При анализе результатов исследования были выявлены следующие особенности топонимов Колосовского района.

1. Подобрать единую методику исследования и классификацию для географических названий данной территории было очень сложно, так как свое происхождение они берут не только из русского, но и из тюркских языков. Поэтому использовались схемы классификации топонимов, предложенные Э. М. Мурзаевым и А. М. Селищевым, а так же географические названия, которые уходят своими корнями в другие языки, выделены в особую группу.

2. Некоторые топонимы района, хотя и имеют происхождение от фамилий и имен людей, на самой деле наименованы по названию уже существующих населенных пунктов. На территории района таковыми являются Владимировка, Николаевка [3], так как их первопоселенцы приехали из других губерний, и увековечили память о своем родном населенном пункте.

3. Перевод некоторых тюркоязычных топонимов затруднителен. При использовании русским населением иноязычных слов, прежние названия изменялись, а часто просто искажались. Это и стало следствием изменения изначального топонима.

Колосовский район - один из 32 районов Омской области, одна маленькая часть большого сибирского региона, топонимы, которого хранят в себе историю, особенности территории и жизни людей.

Подрастающему поколению - школьникам, жителям Омской области необходимо знать свой родной край. Топонимы, которые мы произносим каждый день, открывают многие тайны, хранившиеся целые столетия.

\section{СПИСОК ЛИТЕРАТУРЫ}

1. Мурзаев Э. М. География в названиях / Э. М. Мурзаев. - 2-е изд., перераб. и доп. - Москва : Наука, 1982. - 176 с.

2. Селищев А. М. Из старой и новой топонимики / А. М. Селищев // Труды Московского института истории, философии и литературы. - Москва, 1939. - Т. 5. C. $124-174$.

3. Соколова Е. В. Основные этапы заселения Колосовского района Омской области в XVII-XIX века / Е. В. Соколова // Гуманитарные, социально-экономические и общественные науки. - 2015. - № 11-1. C. 226-229.

4. Соколова Е. В. Особенности заселения территории Коловского района Омской области в XVI XVIII вв. / Е. В. Соколова // Инновационная наука. 2015. - № 10-3. - C. 32-34.

5. Топонимика // Географический энциклопедический словарь: понятия и термины / гл. ред. А. Ф. Трешников. - Москва : Советская Энциклопедия, 1988. C. 309 .

\section{REFERENCES}

1. Murzayev E. M. Geografiya v nazvaniyakh / E. M. Murzayev. - 2-e izd., pererab. i dop. - Moskva : Nauka, 1982. - $176 \mathrm{~s}$.

2. Selishchev A. M. Iz staroy i novoy toponimiki / A. M. Selishchev // Trudy Moskovskogo instituta istorii, filosofii i literatury. - Moskva, 1939. - T. 5. - S. 124-174.

3. Sokolova E. V. Osnovnyye etapy zaseleniya Kolosovskogo rayona Omskoy oblasti v XVII-XIX veka / E. V. Sokolova // Gumanitarnyye, sotsial'no-ekonomicheskiye i obshchestvennyye nauki. - 2015. - № 11-1. - S. 226-229.

4. Sokolova E. V. Osobennosti zaseleniya territorii Kolovskogo rayona Omskoy oblasti v XVI - XVIII vv. / E. V. Sokolova // Innovatsionnaya nauka. - 2015. - № 103. - S. 32-34.

5. Toponimika // Geograficheskiy entsiklopedicheskiy slovar': ponyatiya i terminy / gl. red. A. F. Treshnikov. Moskva : Sovetskaya Entsiklopediya, 1988. - S. 309. 
Кушнарева Ольга Вячеславовна

магистрант направления «Педагогическое образование» Омского государственного педагогического университета, г. Омск

\section{Лазарева Жанна Васильевна}

кандидат географических наук, доцент кафедры географии и методики обучения географии Омского государственного педагогического университета, г. Омск, E-mail: zanna lasareva@inbox.ru
Kushnareva Ol'ga Vyacheslavovna

Master's degree student of «Pedagogical education», Omsk State Pedagogical University, Omsk.

Lazareva Jeanne Vasil'yevna

Candidate of Geographical Sciences, Associate Professor of the Department of geography and methods of teaching geography, Omsk State Pedagogical University, Omsk, E-mail: zanna lasareva@inbox.ru 